Piotr Jeżowski

\title{
ROZWÓJ ZRÓWNOWAŻONY I JEGO NOWE WYZWANIA
}

\section{Wprowadzenie}

Od dwóch dekad świat próbuje się przestawić na drogę rozwoju zrównoważonego, to jest rozwoju uwzględniającego wzajemne związki przyrody, gospodarki i społeczeństwa. Koncepcja rozwoju zrównoważonego (sustainable development) powstała w końcu XX wieku w sytuacji kryzysu ekologicznego, ostrych problemów ochrony środowiska, pułapki energetycznej i problemów społecznych. Kategoria rozwoju zrównoważonego stanowi dziś nieodłączny element nie tylko polityki ekologicznej, lecz także polityki społeczno-ekonomicznej i różnych strategii rozwoju społeczno-gospodarczego zarówno na szczeblu globalnym i ogólnokrajowym, jak i na szczeblu regionalnym i lokalnym. Za rozwojem zrównoważonym przemawia przede wszystkim świadomość przyszłych problemów związanych z przyrodą i jej zasobami, gospodarką i społeczeństwem. Wymóg podążania w kierunku rozwoju zrównoważonego wynika $\mathrm{z}$ faktu, że współcześnie istnieje już daleko idące rozpoznanie, iż obecna droga rozwoju społeczno-gospodarczego i powielanie dotychczasowych trendów wzrostu gospodarczego bez patrzenia na szeroko rozumiane skutki ekologiczne, społeczne i ekonomiczne jest nie do utrzymania w niezbyt odległej perspektywie. Realizacja zasad rozwoju zrównoważonego jest trudnym zadaniem do wykonania w kontekście przyspieszonych procesów globalizacji.

Źródła koncepcji rozwoju zrównoważonego tkwią niewątpliwie w ekonomii klasycznej. Jej przedstawiciele zastanawiali się nad granicami wzrostu, badając spadającą wydajność ziemi uprawnej ze względu na różnicę żyzności, czy też relacje między zasobami ziemi uprawnej a rozwojem ludnościowym. ${ }^{1} \mathrm{~W}$ późniejszym okresie tymi kwestiami zajmowali się w różnym stopniu przedstawiciele ekonomii neoklasycznej, marksizmu, instytucjonalizmu i ekonomii keynsowskiej. Szczególne zasługi w tym zakresie mają przedstawiciele Klubu Rzymskiego, którzy wskazali na naturalne granice wzrostu oraz konieczność ograniczenia zużycia zasobów naturalnych i potrzebę ich ochrony.

${ }^{1}$ H. Rechul, Zasoby naturalne - jak blisko jest koniec dostępności, „,Wokół Energetyki” 2004 nr 4. 
Współcześnie rozwój zrównoważony jest przedmiotem szczególnego zainteresowania przede wszystkim ekonomii ekologicznej (ecological economics). Specyficzne podejście prezentuje neoklasyczna ekonomia środowiska i zasobów naturalnych (environmental and resources economics). Rozwój zrównoważony jest obecny w analizie innych kierunków ekonomii heterodoksyjnej, jak np. ekonomia neoinstytucjonalna, ekonomia postkeynsowska, czy też kierunków zbliżonych do ekonomii głównego nurtu, jak np. nowa ekonomia instytucjonalna czy nowa ekonomia keynesowska. Jest on też nieobcy naukom społecznym, technicznym i przyrodniczym (socjologia, psychologia, termodynamika i analiza energetyczna, inżynieria środowiska, planowanie przestrzenne itp.). Co więcej, tworzą się nowe dyscypliny społeczno-ekonomiczne, które od samego początku biorą za przedmiot zainteresowania tę kategorię, próbując uwzględnić szerszą perspektywę polityki ekologicznej i rozwoju zrównoważonego (m.in. ekologiczna ekonomia polityczna oraz ekonomia socjoekologiczna). Istotny wkład wnoszą tu także ekonomia behawioralna oraz nauki o zarządzaniu, które wskazują na znaczenie wiedzy oraz czynników psychologicznych, etyki i społecznej odpowiedzialności biznesu.

W związku z tym, że rozwój zrównoważony jest przedmiotem zainteresowania tak licznych dyscyplin ekonomicznych, społecznych, przyrodniczych i technicznych, występują poważne problemy definiowania kategorii rozwoju zrównoważonego oraz postrzegania i rozumienia znaczenia kapitału naturalnego i trwałości. Różny jest także wkład poszczególnych dyscyplin naukowych do teorii i praktyki rozwoju zrównoważonego.

\section{Istota rozwoju zrównoważonego a postrzeganie kapitału naturalnego i trwałości}

Rozwój zrównoważony w ogólnym rozumieniu jest globalną koncepcją wykoncypowaną na potrzeby i wyzwania XXI wieku. Jest on oparty na myśleniu systemowym, pozwalającym na zrozumienie wzajemnych i wielorakich związków między środowiskiem a gospodarką i społeczeństwem. Rozwój zrównoważony nie stanowi jednolitej i ściśle zdefiniowanej kategorii. Jest to koncepcja płynna, zmieniająca się czasie i przestrzeni, o różnym zakresie przedmiotowym oraz odzwierciedlająca różnice systemów wartości. Niemniej jednak, mimo swojej wieloznaczności, ma ona lub przynajmniej powinna mieć pewne elementy wspólne, aby nie stała się li tylko chwytem marketingowym bądź słowem-wytrychem. Charakterystyczny musi być długoterminowy punkt widzenia w stosowaniu zasad ochrony środowiska, oszczędnego 
gospodarowania zasobami naturalnymi i zachowania przezorności wobec kapitału naturalnego oraz muszą mu przyświecać zasady sprawiedliwości.

Wyjściowa definicja rozwoju zrównoważonego z raportu G. Brundtland z 1987 roku jest ujęciem uogólnionym i oznacza „,zaspokojenie potrzeb i aspiracji dzisiejszego pokolenia w sposób, który nie ogranicza możliwości zaspokojenia potrzeb przyszłym pokoleniom (path of human progress which meets the needs and aspirations of the present generation without compromising the ability of future generations to meet their own needs)". ${ }^{2} \mathrm{~W}$ istocie jest to podejście normatywne, stanowiące próbę pogodzenia interesów obecnego pokolenia z interesami przyszłych pokoleń, jak również mające na uwadze rozwój społeczny, niemniej jednak pozbawione konkretności i wartości użytecznej wskazówki, jak należy kształtować cele polityki ekologicznej w nawiązaniu do celów polityki gospodarczej i polityki społecznej. ${ }^{3} \mathrm{~W}$ praktycznym wymiarze na potrzeby operacyjne i wdrożenia konieczne jest ściślejsze precyzowanie istoty, zakresu i zasad rozwoju zrównoważonego. Mimo prób uzgodnienia praktycznych zasad rozwoju zrównowazonego i określenia zakresu programów jego wdrożenia postępuje daleko idące zróżnicowanie rozumienia i definiowania rozwoju zrównoważonego. ${ }^{4}$ Obecnie na świecie funkcjonuje co najmniej 100 różnych definicji i interpretacji rozwoju zrównoważonego od skoncentrowanych na rozwoju społeczno-ekonomicznym, a pomniejszających problemy ekologiczne do definicji ogniskujących nacisk na problemy ekologiczne, a ignorujących aspekty rozwoju gospodarczego i społecznego. Stanowi to istotny problem nie tylko teoretyczny i poznawczy, lecz także praktyczny, ponieważ rozwój zrównoważony może być rozumiany i interpretowany na wiele sposobów, a realizowana polityka i strategie rozwoju mogą zawierać zdecydowanie różne treści i mieć odmienny zakres przedmiotowy.

Zasadnicze znaczenie dla istoty kategorii rozwoju zrównoważonego (rozwoju trwałego) ma podstawowy jego filar, na którym się opiera, to jest trwałość (sustainability). Chodzi tu o rozstrzygnięcia dotyczące etycznych przesłanek trwałości, które obejmują sprawiedliwość wewnątrzpokoleniową oraz sprawiedliwość międzypokoleniową i sprawiedliwość wobec bytów nieosobowych, jak również założenia zakresu substytucyjności między usługami świadczonymi przez kapitał naturalny

2 R. Estes, Toward sustainable development: from theory to praxis, „Social Development Issues” 1993 Vol. 15, Nr 3.

3 Według polskiego prawa ochrony środowiska zrównoważony rozwój to „taki rozwój społeczno-gospodarczy, w którym następuje proces integrowania działań politycznych, gospodarczych i społecznych, z zachowaniem równowagi przyrodniczej oraz trwałości podstawowych procesów przyrodniczych, $\mathrm{w}$ celu zagwarantowania możliwości zaspokajania podstawowych potrzeb poszczególnych społeczności lub obywateli, zarówno współczesnego pokolenia, jak i przyszłych pokoleń”. Definicja ta ma cechy konkretności, dobrze oddaje istotę rozwoju zrównoważonego i w sposób wyraźny pomija kwestię równoważenia.

4 Pierwszą próbą uzgodnienia zasad i zakresu rozwoju zrównoważonego była Agenda 21 przyjęta na szczycie Ziemi w Rio de Janeiro w 1992 roku. 
a pozostałymi formami kapitału społecznego (kapitału ludzkiego i kapitału wytworzonego przez człowieka) oraz problem nieodwracalności procesów. Trwałość w dyscyplinach o silnym odchyleniu ekologicznym uznawana jest za jedyne i zasadnicze kryterium rozwoju, natomiast w dyscyplinach o silnym odchyleniu ekonomicznym traktowana jest tylko jako jeden $\mathrm{z}$ elementów pożądanej ścieżki rozwoju. ${ }^{5}$

Nie ma ostatecznej zgody co do tego, czy kategoria trwałości jest obiektywna, czy subiektywna. Zdecydowanie więcej autorów skłania się ku poglądowi, że trwałość jest kategorią subiektywną, ponieważ możliwe są różne stopnie trwałości od słabej, poprzez wyważoną, do mocnej. ${ }^{6}$ Zarzut subiektywizmu jest w pewnej mierze poparty tym, że społeczeństwa jako takie podlegają systematycznej przemianie, w której zmieniają się interesy i wartości, a więc są to kategorie względnie niestabilne. Na subiektywizm może wpływać też to, że przyjmowane założenia trwałości i koncepcje strategii rozwoju zrównoważonego uwzględniają przede wszystkim preferencje tych, którzy nad nimi pracują. ${ }^{7} \mathrm{Na}$ subiektywizm wskazuje również zmienny zakres różnych strategii rozwoju zrównoważonego czy sformułowania prawa ochrony środowiska w poszczególnych krajach.

Przyjmuje się, że przy wyborze stopnia trwałości idzie o to, na jakie kryteria trwałości i jak rozumiane kładzie się nacisk. W zależności od tego akcentowane mogą być bardziej np. problemy przyrody czy też gospodarki lub społeczeństwa. Najbardziej upowszechnione są dwa krańcowe podejścia do definiowania i pomiaru rozwoju zrównoważonego, to jest oparcia się na słabej i mocnej trwałości.

Debata na temat mocnej i słabej trwałości jest w naukach ekonomicznych przedmiotem nierozstrzygniętego sporu. Trwałość słaba bazuje na teorii neoklasycznej i zakłada, że kapitał wytworzony i naturalny są substytutami, a utrata elementów kapitału naturalnego może być kompensowana korzyściami płynącymi z kapitału wytworzonego przez człowieka. Natomiast trwałość mocna reprezentowana przez ekonomię ekologiczną oznacza ograniczoną substytucję przynajmniej kluczowych aktywów kapitału naturalnego z szeroko rozumianym kapitałem społecznym. ${ }^{8}$

Rozwój zrównoważony ma wielowymiarowy charakter, ponieważ zawsze obejmuje mniejszą lub większą liczbę różnych komponentów (ładów). Z drugiej strony

${ }^{5}$ R. Stavins, A. Wagner, G. Wagner, Interpreting sustainability in economic terms: dynamic efficiency plus intergenerational equity, „Economic Letters” 2003 Vol. 79, s. 339-343.

${ }^{6}$ R. Hueting, L. Reijnders, Sustainability is an objective concept, „Ecological Economics” 1998 Vol. 27, s. $139-147$.

7 M. Lambrecht, A. Thierstein, Nachhaltige Entwicklung und Raumordnung, „Raumforschung und Raumordnung" 1998 Nr 2-3.

${ }^{8}$ K. Rennings, H. Wiggering, Steps toward indicators of sustainable development, „Ecological Economics” 1997 Vol. 28, Nr 1. 
na tę cechę wpływa także i to, że rozwój zrównoważony obejmuje nie tylko produkcję i logistykę czy też zmiany technologii, lecz także konsumpcję (sustainable consumption) i procesy społeczne (human development).

Należy jednak wyraźnie podkreślić, że istota rozwoju zrównoważonego nie tkwi w równoważeniu relacji między takimi ładami, jak gospodarka, społeczeństwo, przestrzeń czy przyroda, a w wyborze stopnia trwałości. Stopień trwałości określa nacisk na ochronę środowiska i dążenie do zachowania kapitału naturalnego względem potrzeb gospodarki i społeczeństwa, a sama kategoria rozwoju zrównoważonego z zasady akcentuje nachylenie do ładu ekologicznego. Niemniej jednak możliwość subiektywnego uwzględnienia różnego stopnia trwałości w konsekwencji nadaje rozwojowi zrównoważonemu wielopostaciowość, czy też prowadzi do licznych jego odmian. Co więcej, nie ma w tym zakresie możliwości osiągnięcia jednego uzgodnionego rozwiązania czy jednej zunifikowanej definicji. Konkretne rozwiązania zależą bowiem od czasu, miejsca, wyznawanych wartości i dysponowanych zasobów nie tylko naturalnych, lecz także ekonomicznych i ludzkich. Niezależnie jednak od długotrwałej debaty na temat precyzyjnego określenia koncepcji rozwoju zrównoważonego istnieje szeroki konsens w tej sprawie, że działalność gospodarcza powinna być spójna z:

- użyciem odnawialnych zasobów naturalnych zapewniającym trwałość,

- ochroną właściwości i funkcji ekosystemów,

- zachowaniem bioróżnorodności,

- utrzymaniem szkodliwych emisji poniżej krytycznego progu, to jest zdolności asymilacyjnej,

- $\quad$ unikaniem nieodwracalnych zniszczeń w środowisku i przyrodzie. ${ }^{9}$

Rozwój zrównoważony wymaga zatem stosowania zasady prewencji (prevention principle) i przede wszystkim ostrożnościowej zasady przezorności (precautionary principle, Vorsorgeprinzip). Z drugiej strony należy wyraźnie podkreślić, że rozwój zrównoważony nie jest rozwojem społecznym skoncentrowanym na człowieku i odnoszonym do zdrowia, edukacji i zatrudnienia. Nie jest on również rozwojem gospodarczym, który z natury jest skoncentrowany na produkcji, dochodach i konsumpcji. Rozwój zrównoważony nie może także oznaczać wyłącznie rozwoju ekologicznego (przyrodniczego). Wybór jednej z tych trzech opcji musiałby oznaczać naruszenie sprawiedliwości ekologicznej, społecznej lub ekonomicznej.

W ostatniej dekadzie w rozumieniu pojemności przedmiotowej rozwoju zrównoważonego nastąpiła wyraźna zmiana wynikająca z zasadniczego przesunięcia

9 P. Mulder, J. van der Bergh, Evolutionary economics theories of sustainable development, „Growth and Change" 2001 Vol. 32, Nr 1. 
akcentów. Otóż przed tradycyjne dziedziny problemowe rozwoju zrównoważonego, takie jak odpady, transport, gospodarka materiałowa, energia, woda, żywność, gospodarka przestrzenna i bioróżnorodność, kultura i dziedzictwo kulturowe, sprawiedliwość, gospodarka oraz zdrowie, na pierwsze miejsce wysunęła się ochrona klimatu Ziemi i gospodarka niskowęglowa. Ta nowa hierarchia problemów ma obecnie zasadniczy wpływ kształtowanie priorytetów ekologicznych, społecznych i ekonomicznych zarówno na poziomie globalnym przez instytucje międzynarodowe, jak i na poziomie poszczególnych państw. Niektórzy wręcz utożsamiają ochronę klimatu i gospodarkę niskowęglową z rozwojem zrównoważonym. Takie jednostronne uproszczenie jest merytorycznie nieuzasadnione i jednocześnie stanowi duże intelektualne nadużycie. Sprowadzenie ochrony klimatu do zasadniczego celu rozwoju zrównoważonego byłoby wielkim zubożeniem tej kategorii ekologiczno-ekonomiczno-społecznej.

Kluczowe znaczenie do podejścia poszczególnych dyscyplin naukowych do rozwoju zrównoważonego ma postrzeganie struktury kapitału naturalnego oraz stopnia trwałości. Ekonomia ekologiczna wniosła niezaprzeczalny wkład do definiowania trwałości i do promocji rozwoju zrównoważonego. W aspekcie teoretycznym i normatywnym jest on niemożliwy do podważenia i ominięcia przez dyscypliny pokrewne. Ekonomia ekologiczna opowiada się za troskliwym podejściem do kapitału naturalnego oraz za wysokim stopniem trwałości.

Kategoria kapitału naturalnego w szerszym rozumieniu ekonomii ekologicznej obecnie w znacznej części została przejęta już przez ekonomię środowiska i inne dyscypliny społeczno-ekonomiczne, zajmujące się ochroną środowiska i rozwojem zrównoważonym. Mimo ewolucji i benchmarkingu różnych dyscyplin ekonomicznych w dalszym ciągu jednak utrzymują się różnice w podejściu do kapitału naturalnego. Poszczególne dyscypliny przypisują kapitałowi naturalnemu odmienne właściwości i funkcje.

Ekonomia ekologiczna i zbliżone do niej dyscypliny wyraźnie rozgraniczają kapitał naturalny od kapitału wytworzonego przez człowieka i kapitału ludzkiego. Natomiast ekonomia środowiska i kierunki nurtu głównego nie podkreślają tych różnic. W ekonomii środowiska występuje konwencjonalne rozumienie struktury kapitału łącznego, który składa się z:

- kapitału wytworzonego przez człowieka (human-made capital),

- kapitału ludzkiego (human capital),

- kapitału naturalnego (natural capital). ${ }^{10}$

10 D. Pearce, G. Atkinson, The concept of sustainable development, „Swiss Journal of Economics and Statistics" 1998 Vol. 134, Nr 3. 
W ekonomii środowiska są to czynniki produkcji z cechą doskonalej substytucji. Ekonomistom środowiska zarzuca się, że traktowanie kapitału naturalnego jako zamienny zasób, który może być odnawiany w podobny sposób jak kapitał uprzedmiotowiony i praca, jest dużym uproszczeniem. Ekonomia ekologiczna widzi inaczej gradację typów kapitału pod względem ich ważności:

- kapitał naturalny (ziemia, ekosystemy, zasoby mineralne, zdolność asymilacyjna itp.),

- kapitał ludzki (praca, wiedza, umiejętności, technologie, kultura, stosunki międzyludzkie, organizacja społeczeństwa, instytucje, zasady i normy),

- $\quad$ kapitał wytworzony przez człowieka (budynki, maszyny, infrastruktura itp.). ${ }^{11}$

Ekonomia ekologiczna inaczej także niż ekonomia środowiska patrzy na sam kapitał naturalny. Nie są to tylko, jak w ekonomii klasycznej i neoklasycznej, zasoby naturalne $\mathrm{w}$ formie odnawialnych i nieodnawialnych aktywów ekologicznych. W ekonomii ekologicznej szczególną wagę nadaje tym elementom kapitału naturalnego, które tworzą ekosystemy. Ranga ekosystemów wynika z ich funkcji. Kapitał naturalny w formie ekosystemów świadczy usługi ekologiczne dla produkcji i konsumpcji oraz przede wszystkim dla utrzymania życia na Ziemi (life supporting environmental services). Oznacza to, że kapitał naturalny w ekonomii ekologicznej nie stanowi jednolitej kategorii. Elementy kapitału naturalnego są różnicowane na aktywa ważne i aktywa mniej ważne, czyli na kapitał krytyczny i kapitał pozostały (critical and non-critical natural capital). ${ }^{12}$ Ekonomia ekologiczna wskazuje na zróżnicowaną rolę elementów kapitału naturalnego, a w szczególności rolę i znaczenie krytycznego kapitału naturalnego w formie ekosystemów, który warunkuje system podtrzymujący życie. Stanowisko to podziela większość kierunków heterodoksyjnych.

Klasyfikacja kapitału naturalnego i usług ekologicznych ma istotne znaczenie dla zrozumienia istoty trwałości (sustainability). Warunki brzegowe zachowania całości lub części kapitału naturalnego określają charakter trwałości, która może zmieniać się między trwałością bardzo słabą (very weak sustainability) a trwałością bardzo mocną (very strong sustainability). Zachowanie aktywów kapitału naturalnego wymaga ograniczenia jego użytkowania. W zależności od siły ograniczeń rozróżnia się różne stopnie trwałości. Pierwszy stopień obejmuje stałość sumy kapitału naturalnego ekosystemów, czyli stałość kapitału krytycznego. Odpowiada to trwałości mocnej (strong

11 R. Costanza, Visions, values, valuation, and the need for an ecological economics, „Bioscience” 2001 Vol. 51, Nr 6; D. Pearce, G. Atkinson, The concept..., op.cit.; W. Hediger, Reconciling „,weak” and „strong” sustainability, „International Journal of Social Economics” 1999 Vol. 26, Nr 7-9.

12 C. Collados, T. Duane, Natural capital and quality of life, „Ecological Economics” 1999 Vol. 30, s. 441-460; J. Swaney, Are democracy and common property possible on our small Earth?, „Journal of Economic Issues” 2003 Vol. 37, Nr 2; R. de Groot, M. Wilson, R. Boumans, A typology for classification, description and valuation of ecosystems functions, goods and services, „Ecological Economics” 2002 Vol. 41, s. $393-408$. 
sustainability). Drugi stopień występuje w modelu adaptacyjnym R. Norgaarda. Tutaj substytucja może występować jako element procesu dostosowawczego. Jednakże jest to trwałość bardzo mocna (very strong sustainability), ponieważ proces substytucji jest dopuszczalny tylko w warunkach równowagi między kapitałem naturalnym a wytworzonym przez człowieka. ${ }^{13}$ Trzeci stopień oznacza ograniczenie użytkowania łącznego zasobu różnych form kapitału naturalnego. ${ }^{14}$ Ten warunek występuje w restrykcyjnej koncepcji steady state $\mathrm{H}$. Daly’ego i oznacza, że między kapitałem naturalnym a innymi typami kapitału nie ma miejsca na substytucję. Odpowiada to oczywiście trwałości bardzo mocnej. Trwałość słaba (weak sustainability) - charakterystyczna dla ekonomii środowiska - to stałość sumy kapitału naturalnego, kapitału ludzkiego i kapitału wytworzonego przez człowieka. ${ }^{15}$

\section{Rozwój zrównoważony w ekonomii ekologicznej i ekonomii środowiska}

Ekonomia ekologiczna jest genetycznie w pewnym sensie powrotem do ekonomii klasycznej w wersji maltuzjańskiej. Ekonomia ekologiczna, wybierając trwałość mocną lub bardzo mocną, zdecydowanie kładzie nacisk na trwałość ekologiczną. Analiza trwałości w ekonomii ekologicznej obejmuje wielopokoleniowy horyzont i przede wszystkim sprawiedliwość międzypokoleniową. Ekonomia ekologiczna reprezentuje odchylenie ekologiczne, oparte na zasadach przepływów fizycznych, odrzucające użyteczność i preferencje społeczne jako błędne z powodu ewidentnego prezentyzmu. ${ }^{16}$ Ekonomia ekologiczna patrzy na gospodarkę przez pryzmat tzw. ekologicznego odcisku stopy ludzkiej (ecological footprint). ${ }^{17}$ Ekonomia ekologiczna odrzuca założenie substytucyjności przynajmniej kluczowych elementów kapitału naturalnego z pozostałymi rodzajami kapitału, co ogólnie oznacza konieczność utrzymania odpowiedniej skali działalności człowieka do istniejących rozmiarów aktywów

\footnotetext{
$13 \mathrm{~J}$. Boyce, Ecological economics and political economy; why the twain should meet, Adress to the Inaugural Conference of U.S. Society for Ecological Economics, Duluth, Minnesota, 12 July 2001, s. 2.

14 D. Pearce, G. Atkinson, The concept..., op.cit.

15 T. Żylicz, Ekonomia środowiska i zasobów naturalnych, PWE, Warszawa 2004, s. 197-198.

16 H. Daly, Sustainable development: definitions, principles, policies, Invited address, World Bank, Washington, D.C., April 30, 2002.

17 M. Wackernagel, W. Rees, Perceptual and structural barriers to investing in natural capital: economics from an ecological footprint perspective, „Ecological Economics” 1997 Vol. 20, Nr 1.
} 
ekologicznych, sprawiedliwą dystrybucję między pokoleniami i między gatunkami oraz efektywną alokację zasobów naturalnych. ${ }^{18}$

Bardzo ambitne założenia ekonomii ekologicznej są nierealistyczne, ponieważ każde użycie nieodnawialnych zasobów podważa zasadę bardzo mocnej trwałości, a człowiek w działalności gospodarczej i dla zaspokojenia potrzeb konsumpcyjnych sięga także po kluczowe aktywa naturalne. Odchylenie w kierunku trwałości ekologicznej pomija interesy gospodarki i społeczeństwa w krótkim okresie. Próby ograniczenia skali gospodarki muszą mieć istotny wpływ na funkcjonowanie rynku oraz na dystrybucję dochodów zarówno w ramach obecnego pokolenia, jak i między pokoleniami. ${ }^{19}$ Trwałość mocna lub bardzo mocna bowiem pozostawia niewiele miejsca na rozwój społeczno-gospodarczy i zapewnienie dobrobytu obecnemu pokoleniu. Faktycznie jest to pole wyznaczone możliwościami asymilacyjnymi środowiska i zasobami kapitału naturalnego. W związku z tym wielkie ambicje ekonomii ekologicznej nie znajdują zgody wszystkich aktorów ochrony środowiska i promocji rozwoju zrównoważonego. W rezultacie pojawiają się realne problemy z uzyskaniem społecznej akceptacji rozwiązań opartych na mocnych i bardzo mocnych wariantach trwałości.

Trwałość mocna lub bardzo mocna może być przyjęta bardziej za niedościgły wzorzec niż realistyczny cel do osiągnięcia we współczesnych uwarunkowaniach społeczno-gospodarczych i politycznych. W szczególności dość trudno sprostać tym normatywnym wymaganiom na niższych szczeblach zarządzania ekologicznego, to jest w przedsiębiorstwach i gminach. Tu bowiem zachowanie zasad rozwoju zrównoważonego w mocniejszych wariantach napotyka znacznie więcej ograniczeń niż w sytuacji podejścia mezo- i makroekonomicznego. Na szczeblu lokalnym konieczne jest uwzględnienie nie tylko interesów środowiska, lecz także gospodarki i społeczeństwa (przedsiębiorczość, zatrudnienie, wyrównywanie szans, walka z ubóstwem, dostęp do usług zdrowotnych i edukacyjnych czy też partycypacja w istotnych decyzjach gospodarczych, społecznych i politycznych). ${ }^{20} \mathrm{Z}$ politycznego punktu widzenia nie bez znaczenia jest oczywiście ogólna presja na wzrost płac i rozwój konsumpcji kosztem właściwej polityki ekologicznej. ${ }^{21} \mathrm{~W}$ szczególności mało atrakcyjna jest wizja takiego rozwoju zrównoważonego dla społeczeństw wielu krajów rozwijających się, gdzie na porządku dziennym stoją problemy ubóstwa, głodu, korupcji,

18 B. Norton, R. Costanza, R. Bishop, The evolution of preferences. Why 'sovereign' preferences may not lead to sustainable policies and what to do about it, „Ecological Economics” 1998 Vol. 24, s. 193-211; C. Collados, T. Duane, Natural capital..., op.cit.

${ }_{19}$ M. Stewen, The interdependence of allocation, distribution, scale and stability, „Ecological Economics” 1998 Vol. 27, s. 119-130.

20 Zob. m.in. R. Camagni, R. Capello, P. Nijkamp, Towards sustainable city policy: an economy environment technology nexus, „Ecological Economics” 1998 Vol. 24, s. 103-118.

${ }_{21}$ M. Stewen, The interdependence..., op.cit. 
zadłużenia, warunków higienicznych oraz braku podstawowej opieki zdrowotnej i szerzenia się epidemii. Jest to powodem ewolucji ekonomii ekologicznej polegającej na zastępowaniu koncepcji niskiego wzrostu lub bezwzrostowej nowym podejściem wyrażonym w konkluzji, że rozwój zrównoważony wymaga wzrostu gospodarczego tylko we wczesnym stadium rozwoju kraju, natomiast w długim okresie wzrost gospodarczy nie jest już pożądany jako nie zapewniający trwałości. Zasoby kapitału wytworzonego przez człowieka są wtedy już na tyle wysokie, że należy się skoncentrować na poprawianiu jakości tego kapitału, a nie na jego powiększaniu. ${ }^{22}$

Podejście pragmatyczne i znacznie bliższe realiom, a przede wszystkim wykonalne, oferuje ekonomia środowiska, która reprezentuje odchylenie ekonomiczne oparte na użyteczności i preferencjach, mające na celu poszukiwanie optimum dobrobytu. Ekonomia środowiska w aspekcie rozwoju zrównoważonego koncentruje się na trwałości ekonomicznej i wzroście gospodarczym.

Ekonomia środowiska definiuje i mierzy rozwój zrównoważony w warunkach słabej trwałości, zakładającej, że kapitał naturalny i kapitał wytworzony przez człowieka są substytutami. Dopuszczenie substytucji między tymi czynnikami produkcji otwiera drogę do wzrostu gospodarczego. Jedynie trwałość słaba, w której kapitał naturalny może być zastępowany kapitałem wytworzonym, umożliwia wzrost gospodarczy i rozwój zrównoważony. Ważnym czynnikiem procesów dostosowawczych w ekonomii środowiska jest postęp techniczny i innowacje technologiczne.

Obronie ekonomii środowiska służy ekologiczna krzywa Kuznetza (environmental Kuznets curve - EKC). Krzywa Kuznetza to hipoteza, że relacja między dochodem per capita a zużyciem kapitału naturalnego i wielkością emisji zanieczyszczeń ma kształt odwróconej litery U. Przy niskim dochodzie obciążenie środowiska rośnie w ślad za wzrostem dochodów, a po przekroczeniu pewnego poziomu ma tendencję malejącą. Przyjmuje się, że na kształt krzywej wpływają zmiany wywołane czy też powiązane ze zmianami dochodów i bogactwa. Chodzi tu m.in. o zmiany struktury produkcji i konsumpcji, zmiany zapotrzebowania na usługi środowiska o wyższej jakości, instrumenty internalizacji kosztów zewnętrznych i postęp techniczny w dziedzinie redukcji zanieczyszczeń. W zależności od siły poszczególnych zmian wywołanych dochodami czy też poziomem rozwoju społeczno-gospodarczego zależy tempo wzrostu lub spadku obciążenia środowiska. Inaczej mówiąc, presja ekologiczna maleje wraz ze wzrostem zamożności społeczeństw.

22 J.J. Symoens, Toward sustainable development (recenzja książki P. Lawna), „International Journal of Sustainable Development” 2002 Vol. 5, Nr 2. 
Koncepcja EKC jest na pierwszy rzut oka prosta, logiczna i przemawia do wyobraźni. Pobieżnym obserwatorom automatycznie nasuwa ona następujące wnioski:

- EKC odzwierciedla nie tylko wyniki badań empirycznych, lecz także proste doświadczenia ludzi;

- $\quad$ wzrost gospodarczy nie zawsze jest szkodliwy dla środowiska, ponieważ po osiągnięciu pewnego potencjału może prowadzić do zmniejszania zanieczyszczenia i degradacji środowiska; ${ }^{23}$

- wzrost gospodarczy może stymulować z jednej strony rozwój technologii niskoemisyjnych, oszczędzających zasoby naturalne, $z$ drugiej natomiast prowadzić do szybszej wymiany nieefektywnych i nieekologicznych maszyn, urządzeń i aparatury;

- wzrost popytu na dobra ekologiczne i dobre środowisko może prowadzić do wypychania tzw. brudnych gałęzi przemysłu;

- degradacja środowiska może być spowolniona przez właściwą politykę ochrony środowiska wyposażoną w skuteczne instrumenty.

Wnioski te w konfrontacji z obserwacjami, że od ponad ćwierć wieku w wielu krajach zachodzi proces dematerializacji gospodarki, niejako narzucają myśl, że wystarczające jest umiejętne i racjonalne gospodarowanie zasobami naturalnymi. W związku z tym nie ma potrzeby nadmiernego radykalizmu i wygórowanych ambicji, natomiast wskazane jest umiarkowanie i zawierzenie EKC. Krzywa Kuznetza jest „ciężkim działem” wobec ambitnych dezyderatów ekonomii ekologicznej i rozwoju zrównoważonego opartego na mocnej i bardzo mocnej trwałości. Wnioski wypływające z EKC są w pewnym stopniu powodem ewolucji podejścia do rozwoju zrównoważonego $\mathrm{w}$ wielu dyscyplinach ekonomii heterodoksyjnej.

Wykorzystanie EKC w polityce ekologicznej i wspieraniu rozwoju zrównoważonego musi być jednak ostrożne, aby nie popaść w nieuzasadniony optymizm, że wzrost gospodarczy per se może pomóc środowisku. Nie należy tu oczekiwać nadmiernych efektów bowiem z badań empirycznych wynika, iż EKC sprawdza się tylko w zakresie niektórych zanieczyszczeń. Oznacza to, że EKC nie można uogólniać na wszystkie zanieczyszczenia i wszystkie zasoby naturalne. Zawierzenie EKC może także zwalniać z uwzględniania innych czynników poprawiających środowisko, jak np. stosowania niektórych radykalnych instrumentów ekonomicznych i prawnych czy też przymusowego wdrażania czystych technologii. Krytycy EKC

${ }^{23}$ R. Carson przytacza opinię M. Robinsona sumującą popularny punkt widzenia zwolenników wzrostu gospodarczego pod wymownym tytułem Growth Is the Key to Protecting the Environment, Not Its Enemy w ,Sydney Morning Herald” z 09.09.2008 (R. Carson, The Environmental Kuznets Curve: Seeking Empirical Regularity and Theoretical Structure, http://reep.oxfordjournals.org/content/). 
starają się dowieść, że dobrobyt jest nierozłącznie związany z coraz większym oddziaływaniem człowieka na środowisko, co przeczy ogólnie przyjętemu przekonaniu o tym, że większy dobrobyt powoduje mniej szkód dla środowiska. Wzrost dobrobytu może powodować zmniejszenie ekstensywnego wykorzystania zasobów naturalnych oraz skuteczniejszą kontrolę zanieczyszczeń powietrza i wody. Niemniej jednak nie rozwiązuje problemów innej natury, takich jak rosnące zużycie energii i postępująca emisja gazów cieplarnianych. W szczególności wysoką zależność (elastyczność) od PKB wykazuje emisja $\mathrm{CO}_{2}$, która rośnie tylko trochę wolniej niż wskaźniki wzrostu gospodarczego.

Pozytywną stroną EKC jest to, że zostawia ona miejsce również informacji i wiedzy, przekonaniom ekologicznym oraz kapitałowi ludzkiemu czy samoorganizacji społeczeństwa jako czynnikom, które w pewnej synergii tworzą nacisk polityczny na władze w celu internalizacji kosztów zewnętrznych, sprzyjają powstawaniu rynków dóbr ekologicznych w szerokim znaczeniu tego słowa oraz wpływają na kierunki postępu technicznego i nowych technologii.

Jest także druga, „ciemna” strona krzywej Kuznetza - odwrotne działanie EKC. W sytuacji spadku PKB, problemów finansowych i kryzysu gospodarczego pozytywne skutki EKC mogą się przeradzać symetrycznie w skutki negatywne dla środowiska i rozwoju zrównoważonego, względnie może następować cofanie się korzyści EKC. Wtedy należy oczekiwać, zwłaszcza w społeczeństwach mniej zamożnych, negatywnych zmian zachowań konsumpcyjnych (spadku popytu na dobra ekologiczne) i osłabienia akceptacji wysokich wymogów rozwoju zrównoważonego. W społeczeństwach na dorobku przekonania, postawy i zwyczaje są zbyt wiotkie i nie dość mocno zakorzenione. ${ }^{24}$

Ekonomia środowiska ma niezaprzeczalny dorobek w dziedzinie regulacji środowiska i instrumentów ekonomicznych, chociaż - jak podkreślają krytycy - na wielu polach ma istotne braki, a w szczególności brak odniesienia do dystrybucji międzypokoleniowej, założenie powszechnej substytucyjności oraz brak właściwego stosunku do nieodwracalności zjawisk, czyli w istocie zgoda na nieodwracalne zmiany. ${ }^{25}$ Ponadto podkreśla się łatwe przechodzenie do utożsamiania wzrostu zrównoważonego z rozwojem zrównoważonym oraz koncentrację uwagi na optymalizacji negatywnych efektów zewnętrznych przez zastosowanie instrumentów

24 P. Jeżowski, E. Jastrzębska, P. Legutko-Kobus, E. Taylor, Świadomość ekologiczna polskiego społeczeństwa w warunkach kryzysu, Grant Rektorski SGH 2010, Warszawa, październik 2010, s. 39.

${ }_{25}$ H. Karl, Ökologie, individuelle Freiheit und wirtschaftliches Wachstum: Umweltpolitik in der sozialen Marktwirtschaf, .,Diskussionspapier Reihe B” Nr 97/03, Friedrich-Schiller-Universität Jena, Jena 1997, s. 8; P. Jeżowski, Ekonomia środowiska a ekonomia ekologiczna, w: Ochrona środowiska i ekorozwój, Oficyna Wydawnicza SGH, Warszawa 2000, s. 10-14. 
ekonomicznych. ${ }^{26}$ Optymalizacja negatywnych efektów zewnętrznych nie bardzo pasuje do rozwoju zrównoważonego, zwłaszcza w zakresie sprawiedliwości międzypokoleniowej, ponieważ efekty zewnętrzne tak czy inaczej zawsze mają wpływ na przyszłe pokolenia. Pod wpływem ostrej krytyki ze strony ekonomii heterodoksyjnej ekonomia środowiska ulega ewolucji. ${ }^{27}$ Elementami ewolucji są: uwzględnienie m.in. zmian jakościowych, nieodwracalności, długiego okresu, zwrócenie większej uwagi na kwestię komplementarności aktywów naturalnych i wytworzonych przez człowieka oraz wzajemnych zależności jakości środowiska z dostępnością zasobów i rozwojem ekonomicznym. Oznacza to, że ekonomia środowiska, nie chcąc pozostać martwą dyscypliną, modernizuje swoje podejście do rozwoju zrównoważonego. Na dowód ewolucji mogą służyć sugestie R. Ayresa, który z pozycji obrońcy ekonomii środowiska formułuje racjonalne zalecenia długookresowej trwałości. Wymaga ona oparcia wzrostu gospodarczego bardziej na usługach, a w mniejszym stopniu na uzależnieniu od produktów materialnych i zasobów naturalnych. To oznacza - według niego - że wzrost będzie bardziej zależny od kapitału i pracy, która jest w nadmiarze, a nie od zasobów naturalnych, które stawać się będą coraz szczuplejsze. Kontynuacja wzrostu wymaga zatem radykalnej dematerializacji w powiązaniu ze wzrostem recyklingu zasobów nieodnawialnych napędzanego egzergią słoneczną. ${ }^{28}$

W sukurs ekonomii środowiska przychodzą także nowa ekonomia instytucjonalna i nowa ekonomia keynesowska. W obu tych kierunkach rozwój zrównoważony i trwałość są interpretowane w kategoriach ekonomicznych. Nowa ekonomia instytucjonalna, reprezentowana m.in przez R. Coase'a, D. Northa, R. Posnera i O. Williamsona, uznaje wpływ instytucji na zachowania oraz bada koszty transakcyjne. Niemniej jednak analiza ochrony środowiska i rozwoju zrównoważonego przez nie jest podejściem ilościowym i opiera się na założeniach neoklasycznych i utylitaryzmie, a więc niewiele różni się od rygoryzmu ekonomii środowiska. Tym, co odróżnia ją od ekonomii środowiska, jest wzbogacenie o interdyscyplinarność uwzględniającą prawo, psychologię, socjologię i historię oraz tradycje i dziedzictwo kulturowe. Problemy rozwoju zrównoważonego w nowej ekonomii keynesowskiej w skromnym wymiarze podejmuje przede wszystkim J. Stiglitz.

26 M. Stewen, The interdependence..., op.cit.; P. Jeżowski, Nowe instrumenty ekonomiczne ochrony środowiska a sprawiedliwość wewnątrzgeneracyjna, ,Zeszyty Naukowe Komitetu »Człowiek i Środowisko"” $2001 \mathrm{nr} 29$, s. 95-116.

27 P. Mulder, J. van der Bergh, Evolutionary economics..., op.cit.

28 R. Ayres, Eco-thermodynamics: economics and the second law, „Ecological Economics” 1998 Vol. 26, s. 189-209. 


\section{Rozwój zrównoważony w innych kierunkach ekonomii heterodoksyjnej}

Trudności w zaakceptowaniu rekomendacji ekonomii ekologicznej oraz niedosyt z tytułu minimalizmu ekonomii środowiska stały się podstawą nowych prądów w dotychczasowych kierunkach ekonomii heterodoksyjnej, jak ekonomia neoinstytucjonalna, postkeynesizm i ekonomia behawioralna, oraz czynnikiem tworzenia się nowych kierunków ekonomii, a w szczególności ekologicznej ekonomii politycznej i ekonomii socjoekologicznej. W kierunkach heterodoksyjnych szczególny nacisk kładzie się na czynniki behawioralne, a nie tylko na czynniki ekonomiczne i technologiczne. $Z$ natury zarówno ekonomia ekologiczna, jaki i inne kierunki heterodoksyjne charakteryzują się zdecydowanie podejściem jakościowym w analizie. Heterodoksji nieobcy jest także eklektyzm metodologiczny.

$\mathrm{Z}$ tradycyjnych dyscyplin należy wyróżnić przede wszystkim neoinstytucjonalizm z tworzącą się równolegle ekonomią ewolucyjną oraz postkeynesizm. Ekonomia instytucjonalna w swojej analizie nie odżegnuje się od wpływu czynników ekonomicznych, technologicznych, społecznych, kulturowych i instytucjonalnych, uznając wzajemne ich współzależności. Neoinstytucjonalizm przyjmuje, że dużą rolę w systemie ekonomicznym grają instytucje. Wpływają one poprzez reguły funkcjonowania biznesu i gospodarstw domowych oraz kreatywność, edukację i uczenie się na zmiany technologiczne, a w rezultacie pośrednio na wzorce produkcji i konsumpcji. Wzorce konsumpcji są także warunkowane w sposób bezpośredni edukacją i kulturą ${ }^{29} \mathrm{~W}$ ekonomii neoinstytucjonalnej przyjmuje się za T. Veblenem, że pewne zwyczaje i zachowania są uwarunkowane doświadczeniami. ${ }^{30}$ Instytucje jako takie podlegają określonej dynamice zmian. Neoinstytucjonalizm, podobnie jak postkeynesizm, odchodzi od modelu racjonalnego wyboru na rzecz modelu ograniczonej racjonalności (bounded rationality). Ważnymi punktami zainteresowań neoinstytucjonalizmu są: kategoria dobra wspólnego (common good), wartości społeczne i koszty społeczne. Zaletą neoinstytucjonalizmu jest jego nachylenie mezo- i mikroekonomiczne, a więc w przestrzeni, gdzie rozgrywają się prawdziwe problemy ekologiczne, ekonomiczne i społeczne.

Zasługi neoinstytucjonalizmu i ekonomii ewolucyjnej dla promocji rozwoju zrównoważonego są niezaprzeczalne. Osiągnięcia postkeynesizmu na tym polu są

29 I. Matutinović, An institutional approach to sustainability, „Journal of Economic Issues” 2007 Vol. $41, \mathrm{Nr} 4$.

${ }^{30} \mathrm{~K}$. Marechal, An evolutionary perspective on the economics of energy consumption; the crucial role of habits, „Journal of Economic Issues” 2009 Vol. 43, Nr 1. 
zdecydowanie słabsze. Publikacyjny dorobek postkeynesistów w dziedzinie ochrony środowiska i analiz rozwoju zrównoważonego nie jest szczególnie imponujący. Neoinstytucjonalizm w tym zakresie może się pochwalić takimi wybitnymi osobowościami, jak K. Boulding (ojciec ewolucji w naukach ekonomicznych), W. Kapp, J. Swaney, D. Bromley, E. Ostrom, G. Hodgson, M. Tool, A. Lowe, P. Söderbaum, J. Gowdy, H. Opschoor i Ch. Niggle. Co więcej, niektórzy ważni postkeynesiści są uważani równolegle za neoinstytucjonalistów lub ekonomistów ewolucyjnych (m.in. N. Georgescu-Roegen, R. Wray, M. Forstater, A. Mearman). Znakiem szczególnym jest to, że tylko jeden $\mathrm{z}$ kluczowych współczesnych postkeynesistów na poważnie zajmuje się rozwojem zrównoważonym (P. Davidson). ${ }^{31}$ Poza wymienionymi postkeynesistami związanymi ze środowiskiem i rozwojem zrównoważonym do czołówki zaliczają się jeszcze: R. Holt, M. Lavoie i J. Rosser. Czynnikiem hamującym zainteresowania postkeynsizmu rozwojem zrównoważonym jest jego nachylenie makroekonomiczne oraz postrzeganie - tak samo jak w ekonomii głównego nurtu - konfliktu między wzrostem gospodarczym a środowiskiem. ${ }^{32}$ Oznacza to, że uwaga postkeynesizmu koncentruje się głównie na ładzie gospodarczym i społecznym. ${ }^{33}$

Ekologiczna ekonomia polityczna uwzględnia problemy teorii władzy, a także społeczne problemy związane z pracą oraz rolę instytucji społecznych, zwłaszcza lokalnych instytucji politycznych i społecznych. Na gruncie tej dyscypliny formułowane są zalecenia odejścia od technicznego i obiektywnego podejścia ekonomii środowiska oraz odrzucenia neoklasycznego rachunku ekonomicznego i wyceny wartości ekonomicznych. Nowym elementem jest uwzględnienie terytorium samorządu i państwa. Stąd też istotne znaczenie mają tu reformy instytucji oraz rozwój społeczno-gospodarczy. Dyscyplina zakłada holistyczne widzenie kapitału naturalnego i społecznego w szerokim znaczeniu tego słowa. Jedną z rekomendacji ekologicznej ekonomii politycznej, wspierającą ekonomię ekologiczną, jest tzw. zielona gospodarka (green economics). Oznacza ona małą skalę działalności, samoregulację, partycypację, decentralizację, zielone osiedla i miasta oraz brak opozycji kapitału prywatnego do kapitału publicznego.

W ekonomii socjoekologicznej istotne jest założenie, że człowiek jest elementem natury, a nie tak jak w ekonomii ekologicznej elementem wyobcowanym z kapitału

31 A. Mearman, Post-Keynesian economics and environment, „International Journal of Environment, Workplace and Employment" 2005 Vol. 1, Nr 2.

$32 \mathrm{~J}$. Courvisanos, A post-Keynesian innovation policy for sustainable development, ,International Journal of Environment, Workplace and Employment" 2005 Vol. 1, Nr 2; A. Mearman, Why have post-Keynesian had (relatively) little to say on the economics of the environment?, „International Journal of Environment, Workplace and Employment" 2005 Vol. 1, Nr 2.

${ }_{33}$ M. Forstater, An institutionalist post-Keynesian methodology of economic policy with an application to full employment, ,,Working Paper” Nr 18, University of Missouri, Kansas City 2004, s. 2. 
naturalnego. Jednak sama jednostka nie jest szczególnym przedmiotem rozważań, ważniejsze miejsce mają tu grupy społeczne i społeczeństwo. Z jednej strony uwzględnia się tu wartości etyczne właściwe dla jednostek, $\mathrm{z}$ drugiej natomiast kulturę organizacyjną, zwłaszcza organizacji rządowych i samorządowych, oraz procesy uczenia się indywidualnego i grupowego. Ekonomia socjoekologiczna przykłada wielką wagę do wiedzy społecznej, kształtowanej przez partycypację i praktyczne działanie w zespołach, edukację ekologiczną (szkolenia) i otwarte dyskusje. Wiedza społeczna stwarza warunki do poprawnego wartościowania środowiska i dóbr ekologicznych; jej brak zaniża wycenę. ${ }^{34}$ Wiedza i partycypacja społeczna mogą także dobrze przysłużyć się wypracowaniu, akceptacji i realizacji różnych strategii rozwoju zrównoważonego. Ogniskiem zainteresowań tej dyscypliny jest trwałość społeczna i społeczna sprawiedliwość. Skoncentrowanie uwagi na trwałości społecznej (social sustainability) ma z jednej strony lepiej wyjaśniać zachowania ekonomiczne i społeczne oraz ich skutki, z drugiej zaś poprzez partycypacyjne i elastyczne procesy dochodzenia do rozwoju zrównoważonego pozwolić uniknąć potencjalnych konfliktów. ${ }^{35}$

Duże nadzieje wiąże się z ekonomią behawioralną, która w znacznej mierze bada procesy podejmowania decyzji i zachowania konsumentów, wyjaśniając prawdziwe przyczyny dokonywanych wyborów, odchylenia od logiki ekonomii (w tym zachowania altruistyczne wychodzące poza racjonalność). Ekonomia behawioralna uznaje granice racjonalności czynników ekonomicznych (podobnie jak większość kierunków heterodoksyjnych), uzupełniając swoją analizę oddziaływaniem czynników psychologicznych, heurystyki dostępności i zakotwiczenia, efektu posiadania i innych anomalii. Ekonomia behawioralna opiera się na psychologii społecznej i psychologii indywidualnej i jest blisko spowinowacona z naukami o zarządzaniu. Wprawdzie największe sukcesy ekonomia behawioralna święci w dziedzinie finansów, jednakże wnioski z badań ekonomii behawioralnej mogą być przydatne dla kształtowania polityki ochrony środowiska i wspierania rozwoju zrównoważonego przede wszystkim poprzez dogłębne wyjaśnianie czynników wpływających na wartościowanie dóbr ekologicznych. Ważny jest tu m.in. dorobek D. Kahnemana i A. Tversky'ego.

Nowe dyscypliny mają swoje zakotwiczenie w heterodoksyjnych kierunkach ekonomii i niewiele wspólnego z ekonomią głównego nurtu. W szczególności czerpią one wiele z dorobku neoinstytucjonalizmu i jego odłamu w postaci ekonomii ewolucyjnej, postkeynesizmu, ekonomii marksistowskiej, ekonomii radykalnej oraz socjologii ekonomicznej i psychologii społecznej. Nowe dyscypliny są próbą racjonalnego

${ }_{34}$ S. Farber, R. Costanza, M. Wilson, Economic and ecological concepts for valuing ecosystem services, „Ecological Economics” 2002 Vol. 41, s. 375-392; R. de Groot, M. Wilson, R. Boumans, A typology..., op.cit.

35 J. Cameron, Applying socio-ecological economics, „Ecological Economics” 1997 Vol. 23, s. 155-165; F. Gale, Theorizing power in ecological economics, „Ecological Economics” 1998 Vol. 27, s. 131-138. 
wykorzystania dorobku ekonomii ekologicznej i ekonomii środowiska poprzez stworzenie nowej syntezy i redefinicję relacji między kapitałem naturalnym a kapitałem społecznym, organizacjami i sferą polityczną. Dodatkowym przedmiotem ich zainteresowania staje się władza, instytucje publiczne, społeczeństwo i grupy społeczne czy nawet dziedzictwo kulturowe. Nowe dyscypliny obok trwałości ekologicznej i ekonomicznej w większym stopniu uwzględniają trwałość społeczną, polityczną i kulturową.

Wydaje się, że procesy ewolucji dotychczasowych dyscyplin i tworzenie się nowych wskazują na to, iż w erze rozwoju zrównoważonego generalnie nie ma miejsca na powrót do ekonomii głównego nurtu w jej czystej postaci. Rozwój zrównoważony nie zostawia bowiem wiele miejsca na ekonomię opartą na paradygmatach czy też na upraszczających założeniach. Rozwój zrównoważony dzieje się w realnym świecie - we współczesnej rzeczywistości. Dodatkowym czynnikiem ujawniającym słabości ekonomii mainstream jest obecna sytuacja kryzysowa oraz czas destabilizacji i zamętu na różnych szczeblach zarządzania.

W rekapitulacji należy stwierdzić, że w strategiach rozwoju zrównoważonego ważne jest uwzględnienie nie tylko sprawiedliwości wobec przyszłych generacji oraz świata roślin i zwierząt (trwałość ekologiczna), lecz także interesów obecnego pokolenia, w tym zwłaszcza grup biedniejszych (trwałość ekonomiczna i społeczna), ze względu na społeczną i polityczną akceptację. Racjonalny wybór trwałości leży w przestrzeni zakreślonej między podejściem ekonomii ekologicznej i ekonomii środowiska. Podejścia neoinstytucjonalizmu, ekonomii ewolucyjnej, ekonomii behawioralnej oraz nowych dyscyplin, zwłaszcza ekologicznej ekonomii politycznej i ekonomii socjoekologicznej, starają się uwzględnić uwarunkowania społeczne i polityczne poprzez próby integracji elementów ekonomii, ekologii, zarządzania, socjologii i politologii z uwzględnieniem dynamiki różnych struktur organizacyjnych i ich kultur. W szczególności zapewnienie i zachęta do partycypacyjnego i świadomego charakteru tworzenia strategii rozwoju zrównoważonego pozwala na uniknięcie wielu konfliktów i sprzeczności interesów. Złagodzone podejście w innych kierunkach heterodoksyjnych względem ekonomii ekologicznej jest bliższe realiom społeczno-ekonomicznym i stwarza lepsze perspektywy na większą akceptację społeczną polityki ekologicznej i strategii rozwoju zrównoważonego, aby w ostateczności zwiększyć skuteczność zarządzania rozwojem zrównoważonym. Rozwój zrównoważony w ujęciu mniej dogmatycznym uwzględniający też rozwój społeczno-ekonomiczny jest szansą nie tylko ograniczania degradacji środowiska, lecz także podnoszenia i wyrównywania dobrobytu społecznego.

Rozwój zrównoważony to coś znacznie więcej niż ochrona środowiska. Przejście $\mathrm{z}$ ochrony środowiska do rozwoju zrównoważonego nie tylko $\mathrm{w}$ aspekcie 
semantycznym, postrzegania, rozumienia i definiowania, lecz także implementacji oznacza konieczność bardziej kompleksowego i holistycznego ujmowania zagadnień. W tej sytuacji potrzebne jest odejście od monizmu na rzecz pluralizmu naukowego, interdyscyplinarności, a niekiedy również dopuszczenia pewnego zakresu eklektyzmu. $\mathrm{Z}$ jednej strony konieczne jest wejście w strukturę kapitału naturalnego i jego funkcje, istotę trwałości, ocenę wartości ekologicznych, ekonomicznych i społecznych, rozpoznanie niuansów i osobliwości różnych definicji rozwoju zrównoważonego, $\mathrm{z}$ drugiej natomiast objęcie analizą nie jednego, ale co najmniej trzech rozległych ładów (ekologicznego, gospodarczego i społecznego) w ich wzajemnych związkach i integracji na różnych szczeblach podejmowania decyzji grupowych i indywidualnych czy na różnych poziomach zarządzania.

\section{Presja na środowisko i zasoby a rozwój zrównoważony}

Cechą charakterystyczną obecnego etapu rozwoju cywilizacji w wymiarze globalnym jest szybki rozwój populacji ludzkiej, w tym urbanizacja, gwałtowny rozwój gospodarek wschodzących oraz wzrost globalnej konsumpcji i rosnące zapotrzebowanie na ograniczone zasoby naturalne, $\mathrm{w}$ tym przede wszystkim na zasoby energetyczne. Te wszystkie czynniki prowadzą do nadmiernej eksploatacji kapitału naturalnego oraz zanieczyszczenia środowiska. W sumie więc rodzi to potężne zagrożenie dla trwałości ekologicznej. Presja wzrostu demograficznego, produkcji i konsumpcji oraz gospodarki energetycznej na środowisko nie tylko zmienia strukturę gospodarki globalnej i przekształca społeczeństwo, lecz także grozi deficytami energetycznymi, przepływem nadmiernych transferów pieniężnych do krajów surowcowych, dewastacją środowiska i stratami bioróżnorodnosci oraz zmianami klimatycznymi.

Procesy te występowały i w przeszłości, niemniej jednak obecna ich skala stała się na tyle wielka, że bilanse produkcji, konsumpcji, energii, surowców, szkód ekologicznych wskazują na ogromne trudności, przed jakimi w krótkim czasie może stanąć społeczność globalna. Co więcej, nie ma w istocie jasnych mechanizmów wypracowanych na poziomie globalnym, jak te problemy skutecznie rozwiązać. Postęp w dziedzinie uzgodnień międzynarodowych dotyczących konkretnych zadań, finansowania i pomocy dla krajów biedniejszych jest - jak dotąd - za mały, bowiem zasadnicze programy naprawy sytuacji napotykają stały opór (m.in. przez unikanie partycypacji we wspieraniu finansowym ze strony bogatszych państw), w związku z czym są zmiękczane i przenoszone na okresy późniejsze. Obecny globalny kryzys gospodarczy z pewnością nie sprzyja poprawie sytuacji. 
W ujęciu globalnym zasadniczym i pierwotnym czynnikiem presji na środowisko są rozmiary i dynamika gospodarki światowej. Globalizacja wyraźnie przyspieszyła wzrost produkcji dóbr i usług. Zmienia się jej struktura oraz pozycja gospodarek narodowych. W szczególności zauważalny jest ogromny awans gospodarek Chin i Indii. Ostatnia dekada to także wzrost gospodarek Rosji, Brazylii, Meksyku, Turcji i Indonezji. O ile USA w dalszym ciągu zachowują swój 25\% udział w globalnym PKB w okresie po 1990 roku, o tyle Unia Europejska powoli obniża swoje znaczenie jako globalnego gracza (odpowiednio z 27\% do 20\%). Słabnie też potęga gospodarki japońskiej, której udział w globalnym PKB obniżył się z 15\% do 8\%. W tym okresie Chiny notują wzrost udziału z 3\% do $11 \%$. Chiny współczesne to już nie tylko gospodarczy lider azjatycki, lecz także światowy. De facto Chiny są już od 2009 roku drugą narodową potęgą gospodarczą na świecie, gdy jeszcze pięć lat temu nie stratyfikowano chińskiej gospodarki wyżej niż na czwartym miejscu. ${ }^{36}$ Chiny systematycznie detronizują dotychczasowych liderów globalnych (np. eksport - Niemcy, rynek samochodowy - USA), ale także niechlubnie prowadzą w emisji zanieczyszczeń środowiska. Chiny już dziś decydują o 1/5 światowej gospodarki nie tylko w zakresie produkcji przemysłowej i zużycia energii, lecz także zapotrzebowania na surowce i półprodukty. Prognozy przewidują dalszy spadek udziału UE i Japonii w globalnym PKB, gdy udział Chin może sięgnąć za trzy-cztery lata nawet $20 \%$. Ocenia się, że mimo globalnego kryzysu finansowego gospodarki wschodzące mają znacznie większe szanse na podtrzymanie dotychczasowego tempa wzrostu gospodarczego. W grupie gospodarek wschodzących możliwy jest wzrost gospodarczy w następnych latach w granicach 6-7\% rocznie, przy czym Chiny mogą osiągnąc jeszcze wyższe wskaźniki wzrostu (powyżej 9\%). ${ }^{37}$ Równolegle wzrost gospodarczy w USA i UE nie przekroczy $2 \%$.

Warto również zwrócić uwagę, że w gospodarkach wschodzących zmienia się istotnie PKB per capita. I tak na przykład w Chinach, według danych HSBC, PKB na głowę w latach 2000-2006 wynosił nieco ponad 1 tys. dol., w 2008 roku przekroczył 3 tys. dol., a w 2010 roku wyniósł już 4,4 tys. dol., czyli znacznie więcej niż prognozowano trzy-pięć lat temu.

Skutkiem globalizacji jest bez wątpienia serwicyzacja gospodarek zachodnich. Jest to konsekwencja przenoszenia produkcji wyrobów, półwyrobów i prostych podzespołów do gospodarek wschodzących. Serwicyzacja gospodarki z punktu widzenia rozwoju zrównoważonego jest korzystna in situ, ponieważ radykalnie zmniejsza się

36 Zob. m.in. A. Wysocki, China's increasing demand for energy and its impact on environment and world economy, Conference paper Globalisation, energy and environment, Warsaw School of Economics, Warsaw, 29-30 May 2008 , s. 4.

37 J. Redwood, Trends in globalisation and the world economy (prezentacja PPT), House of Parliament, London 2008, s. 30 . 
wtedy obciążenie środowiska i zapotrzebowanie na energię. ${ }^{38}$ Jednakże w rachunku ciągnionym trzeba te procesy inaczej postrzegać, ponieważ w istocie serwicyzacja tylko przenosi presję na środowisko do gospodarek wschodzących, co niewątpliwie statystycznie pozwala gospodarkom wysoko rozwiniętym na wykazanie się wysokimi osiągnięciami ekologicznymi i bardzo dobrymi wskaźnikami rozwoju zrównoważonego. Notabene, presja na środowisko globalne z pewnością byłaby mniejsza, gdyby produkcja przemysłowa nie była przenoszona do gospodarek wschodzących, ponieważ można byłoby wtedy oczekiwać zwiększonego efektu krzywej Kuznetza z uwagi na wyższy poziom technologii produkcji i szerszy zakres czystych technologii.

W ślad za wzrostem gospodarczym w szybkim tempie zwiększa się konsumpcja globalna, tworząc swego rodzaju nośną marketingowo kategorię perswazji moralnej - „bomby konsumpcyjnej”. Zmiany dochodów gospodarstw domowych w krajach gospodarek wschodzących są imponujące i tworzą ogromny potencjał konsumpcyjny. I tak na przykład dyspozycyjny dochód mieszkańców miast per capita w Chinach wzrósł z 478 juanów w 1980 roku do 15781 juanów w 2008 roku (to jest do wartości około 2 tys. dol. am.). Jednocześnie dyspozycyjny dochód per capita mieszkańców wsi zwiększył się w tym okresie ze 191 do 7761 juanów..$^{39}$ Pokazuje to nie tylko dynamikę, ale również relacje dochodów miejskich do reszty kraju, to jest mieszkańców wsi i mniejszości narodowych (np. Tybet).

W gospodarkach wschodzących najważniejszy jest jednak wzrost konsumpcji klasy średniej. Należy zgodzić się z F. Krawcem, że największe zagrożenie dla rozwoju zrównoważonego w obszarze konsumpcji niesie zmiana struktury społecznej wyrażająca się wzrostem wielkości i znaczenia klasy średniej. To, co w klasie średniej ma znaczenie dla pozytywnych stron rozwoju społeczno-gospodarczego (otwartość, przedsiębiorczość, wiedza i umiejętności, dynamika społeczna itp.), z punktu widzenia środowiska może stanowić i stanowi ogromne zagrożenie. Tylko w latach osiemdziesiątych i dziewięćdziesiątych XX wieku aż po $200 \mathrm{mln}$ osób w Chinach i Indiach przemieściło się ze wsi do miast, unikając biedy i awansując społecznie. Zatrudnienie i wzrost dochodów stawia przed klasą średnią zwiększone możliwości konsumpcyjne oraz pokusę realizacji amerykańskiego snu (american dream) w lokalnym wydaniu, niemniej jednak z własnym domem, własnym samochodem i gadżetami elektronicznymi i audiowizualnymi ${ }^{40}$ Chiny i Indie stają się wielkimi rynkami dóbr luksusowych uznanych marek światowych. Dowodem na to są m.in. sukcesy

\footnotetext{
38 Serwicyzacja stawia jednak na poważnie problem trwałości ekonomicznej gospodarki i odporności na zakłócenia gospodarcze i kryzysy (np. przypadek Islandii).

39 I. Johnson, China defends minorities policy, ,Wall Street Journal” 22.07.2009.

40 F. Krawiec, Główne przyczyny globalnego kryzysu energetycznego, w: Planowanie i zarządzanie wenergetyce, red. nauk. P. Borowski, M. Powałka, Wydawnictwo SGGW, Warszawa 2009, s. 8-10.
} 
niemieckich producentów samochodów w sprzedaży aut wysokiej klasy. Mimo kryzysu gospodarczego sprzedaż tych aut np. na rynku chińskim rośnie w niespotykanym tempie kilkudziesięciu procent rocznie. ${ }^{41}$ Deweloperzy budują domy i apartamenty o ogromnych powierzchniach, a przy tym dość niskich normach efektywności energetycznej. ${ }^{42}$ Procesy te nie są tylko typowe dla Chin i Indii, lecz dotyczą także innych gospodarek wschodzących, co najbardziej widać w głównych aglomeracjach takich państw, jak Indonezja, Wietnam, Tajlandia, Brazylia, Rosja, Turcja czy też stolicach państw Zatoki Perskiej i Europy Środkowej.

Przemiany demograficzne, kopiowanie wzorców konsumpcji krajów wysoko rozwiniętych i wysokie tempo rozwoju konsumpcji stwarzają realne zagrożenia, że przyroda światowa i zasoby naturalne staną się naprawdę wąskimi gardłami nie tylko rozwoju zrównoważonego, lecz także postawią wiele społeczeństw przed niemożnością zaspokojenia podstawowych potrzeb ludzkich. Adaptacja rozrzutnego amerykańskiego stylu życia przez klasy średnie musi dużo kosztować środowisko przyrodnicze i naruszać zasoby naturalne. Oddziaływanie procesów konsumpcyjnych trzeba widzieć także w kontekście tego, że Chiny, Indie i wiele innych gospodarek wschodzących znajduje się dopiero na początku budowy gospodarki kapitalistycznej. Spraw tych nie łagodzi fakt, że w wielu omawianych krajach poziom życia jeszcze daleko odbiega od standardów północnoamerykańskich czy zachodnioeuropejskich. Czynnikiem korygującym na niekorzyść dla rozwoju zrównoważonego jest liczba ludności krajów rozwijających się. ${ }^{43}$

Prognozy demograficzne, prognozy produkcji przemysłowej i prognozy energetyczne przewidują, że Chiny tylko do 2020 roku zwiększą zużycie węgla dwa razy, ropy naftowej dwa i pół raz i trzy i pół razy gazu ziemnego, co się przełoży na dwukrotny wzrost emisji $\mathrm{CO}_{2}, \mathrm{NO}_{\mathrm{x}}$ oraz prawie dwukrotny wzrost emisji SO2, o ile nie

${ }^{41}$ Ch. Raulwald, Audi's China sales, „Wall Street Journal” 29.10.2009.

${ }^{42}$ F. Krawiec, Główne przyczyny..., op.cit.

43 O ile wskaźniki konsumpcji w krajach rozwiniętych i gospodarkach wschodzących charakteryzuje wzrost, o tyle rejon Afryki praktycznie od 1970 roku wykazuje całkowitą stagnację w stosunku do pozostałych krajów rozwijających się. Afryka w przeciwieństwie do Ameryki Łacińskiej i Azji charakteryzuje się zbiegiem niskich dochodów, niskich wskaźników rozwoju społecznego (np. korupcja, brak opieki zdrowotnej i edukacji, choroby, wysoka umieralność, niskie oczekiwane trwanie życia czy niskie HDI, lokalne wojny, upadek rolnictwa i produkcji żywności oraz ogólnie niewielka liczba i niskie tempo pozytywnych zmian). Afryka nie uniknęła także klęsk ekologicznych, takich jak degradacja gleby i erozja, deforestacja oraz degradacja zasobów wodnych. Miarą powagi tych problemów jest to, że na kontynencie połowa mieszkańców żyje poniżej bardzo restrykcyjnego wskaźnika ubóstwa według Banku Światowego, czyli 1,25 dol. am. według siły nabywczej. Sytuacja w tym zakresie niewiele się poprawia, mimo że strumień pomocy międzynarodowej praktycznie od połowy lat siedemdziesiątych jest 5 razy większy niż dla pozostałych krajów rozwijających się. Afryka nie partycypuje ani w pozytywnych efektach globalizacji, ani w rewolucji technologicznej czy zielonej rewolucji w rolnictwie. W. Easterly, Can the West save Africa?, „Journal of Economic Literature” 2009 Vol. 47, Nr 2, s. 373-447. 
podejmą skutecznych działań proekologicznych i nie zastosują się do zaleceń podobnych do takich, jakie formułowano w protokole z Kioto. ${ }^{44}$

W najbliższym czasie mimo zjawisk kryzysowych należy spodziewać się dalszego wzrostu gospodarczego w Chinach, Indiach i innych gospodarkach wschodzących. Ten kierunek rozwoju gospodarczego i jego natężenie w istotnym stopniu wpłynie na dalsze krótkookresowe i średniookresowe obciążenie środowiska i zasobów naturalnych. Nie zostanie to skompensowane lepszymi wynikami USA i Unii Europejskiej na skutek spadku populacji w UE oraz wdrożenia skutecznych przedsięwzięć ekologicznych. Zmiany pozytywne należy widzieć raczej w długim okresie, o ile główni aktorzy globalnej gry dotrzymają obietnic i uzgodnią stanowiska a w konsekwencji podejmą realne działania.

Dostępne dane pokazują, że w XXI wieku przyrost emisji $\mathrm{CO}_{2}$ będzie wywołany przez kraje rozwijające się przy stabilizacji emisji w krajach rozwiniętych. Międzynarodowa Agencja Energetyki szacuje dla wariantów nieuwzględniających wspólnej, międzynarodowej akcji na rzecz ograniczania $\mathrm{CO}_{2}$, że do 2030 roku 3/4 wzrostu globalnej emisji $\mathrm{CO}_{2}$ pochodzić będzie z Chin, Indii i Bliskiego Wschodu. Natomiast aż $97 \%$ przyrostu emisji $\mathrm{CO}_{2}$ obejmie państwa spoza organizacji OECD (kraje rozwijające się). ${ }^{45}$

Kluczem obciążenia środowiska w sektorze energetycznym jest produkcja energii elektrycznej. Globalna produkcja energii elektrycznej rośnie i w dalszym ciągu będzie rosnąć. W ostatnich dwudziestu latach produkcja energii zwiększyła się dwukrotnie. W ostatnim okresie tylko w UE, USA, Kanadzie i Meksyku produkcja energii minimalnie maleje dzięki racjonalizacji zużycia energii i efektowi przenoszenia energochłonnej produkcji poza obszar Unii i Ameryki Północnej. ${ }^{46}$ Regionami decydującymi o wzroście produkcji energii elektrycznej są Chiny, Indie i Środkowy Wschód. Afryka i Ameryka Środkowa i Południowa nie mają znaczącego wpływu na globalną emisję zanieczyszczeń z tego tytułu. W ocenie poziomu i dynamiki produkcji i konsumpcji energii elektrycznej należy uwzględnić, że obecnie około 2 mld ludzi na świecie nie ma dostępu do sieciowej energii elektrycznej. ${ }^{47}$

Dotychczas walka z ociepleniem klimatu była niechętnie postrzegana w USA i Chinach. Natomiast w Indiach praktycznie pominięta w polityce gospodarczej i ekologicznej, ponieważ priorytetem jest tam zapewnienie bezpieczeństwa dostaw

44 Z. Weisheng, M. Hailin, N. Ken'ichi, Predictions on energy consumption and emissions in China, „Journal of Policy Science” 2007 Vol. 1, s. 19-33.

45 World energy outlook 2008. Syntesis, OECD-IEA, Paris 2008, s. 14.

${ }^{46}$ Kryzys omija światowa energetykę, „Gazeta Prawna” 29.07.2009; J. Balcewicz, Polska energetyka liderem regresu?, ,Energia Gigawat” $2009 \mathrm{nr} 7-8$.

47 E. Duda, Tylko najedzony człowiek może myśleć o zdrowym odżywianiu, „CIRE.PL” 20.11.2009. 
energii elektrycznej, a nie walka z globalnym ociepleniem. Uznaje się, że w 2009 roku nastąpiła wyraźna zmiana podejścia USA i głównych gospodarek wschodzących w kwestii środowiska i walki z ociepleniem klimatu. Miało się zmienić nastawienie administracji B. Obamy i Chin. Jest to o tyle ważne, że bez USA i Chin wszelkie rozwiązania globalne w sprawie redukcji $\mathrm{CO}_{2}$ nie mają sensu, co pokazuje trwający już sześć lat europejski handel gazami cieplarnianymi (EU ETS) bez żadnego wpływu na światowe wskaźniki ocieplenia, a prowadzony wysokim kosztem z wprowadzeniem zamętu i niepewności w europejskich systemach energetycznych. ${ }^{48}$ Bez głównych globalnych emitentów $\mathrm{CO}_{2}$ europejski handel emisjami jest strategią szkodliwą dla gospodarki UE i strategią kopania się z koniem dla klimatu Ziemi. J. Gray wyraźnie szydzi ze strategii klimatycznej UE, pisząc, że „Europa naiwnie oczekiwała, że USA i Chiny pójdą zaproponowaną przez nią drogą szybkiego przestawienia się na niskoemisyjną, ale kosztowną energetykę". ${ }^{49}$ Faktycznie, dążenie UE do niskich pułapów emisji $\mathrm{CO}_{2} \mathrm{w}$ pojedynkę bez głównych gospodarek globalnych to dalsza dezidustrializacja Europy i jednocześnie Europa niewiele może pomóc klimatowi ze względu na to, że udział UE w globalnej emisji $\mathrm{CO}_{2}$ nie jest na tyle duży, żeby osiągnięcia UE w redukcjach $\mathrm{CO}_{2}$ miały jakikolwiek wpływ na obniżenie globalnej emisji tego gazu.

W 2009 roku USA, Chiny i Indie ogłosiły bardzo ambitne narodowe plany w sprawie zmian klimatu. Niektórzy uznali, że Chiny mogą stać się liderem w walce o klimat, nie mówiąc już o pozytywnym wpływie włączenia się USA i ChRL w odnowienie porozumienia o redukcji $\mathrm{CO}_{2}$ jako tzw. Kioto II czy a post-2012 agreement). ${ }^{50}$ Chodziłoby o porozumienie uzupełnione konkretnym wsparciem finansowym państw potrzebujących. Zielony fundusz klimatyczny ma jak dotąd charakter blankietowy. Nierozstrzygnięta jest wielkość funduszu i źródła pochodzenia środków oraz kto miałby go nadzorować. Szybko jednak okazało się, że te plany są przedmiotem marketingu politycznego. Potwierdza to brak zgody USA i Chin na podpisanie porozumienia zastępującego protokół z Kioto, które mogłoby urealnić politykę klimatyczną UE i zachęcić większość państw do partycypacji w porozumieniu. Jeśli ta dwójka nie zgodzi się ze sobą w tej sprawie, to trudno się spodziewać, aby uczyniły

48 Polityka klimatyczna UE zakłada znaczący wpływ na obniżenie emisji CO2 technologii wychwytywania i magazynowania tego gazu (carbon capture and storage - CCS). Jak dotąd, są to jednak technologie nieopanowane technicznie, a przy tym wymagające wysokich nakładów inwestycyjnych i drogie w eksploatacji. Elektrownie, które wprowadzą programy CCS, staną się całkowicie niekonkurencyjne względem pozostałych. P. Jeżowski, Koszty polityki klimatycznej UE dla polskich przedsiębiorstw energetycznych, Międzynarodowa konferencja naukowa pt. „Przedsiębiorstwa wobec zmian klimatu”, SGH, L'Université de Paris XIII, Warszawa, 7-8 kwietnia 2011, s. 16-17, www.sgh.waw.pl/instytuty/imsg/ccc2011pdf

49 J. Gray, Ekologia napędza rozwój kapitalizmu, „Dziennik Gazeta Prawna” 24-26.12.2010.

50 Waga walki z $\mathrm{CO}_{2}$ w Chinach i USA leży w tym, że są to najwięksi na świecie producenci i konsumenci węgla. Na łączne zużycie węgla na świecie w wysokości około 6 mld t Chiny zużywają 2,7 mld t, a USA - 1 mld t. W. Kotowski, Zrównoważyć rozwój..., „Energia Gigawat” 2010 nr 1-2. 
to inne kraje. To jednak, czy Chiny są gotowe, zależy w dużej mierze od tego, czy gotowa jest Ameryka. ${ }^{51}$ Trzeba też tu widzieć opór strony indyjskiej, która dąży do uznania za miarodajne wskaźniki emisji per capita, a nie całkowitych emisji przypadających na poszczególne państwa, czyli z uwzględnieniem odcisku stopy ludzkiej. Negatywny wynik konsultacji międzynarodowych nietrudno było przewidzieć: w Durbanie (RPA) nie doszło do zasadniczego przełomu.

Sytuacja kryzysowa dodatkowo nie sprzyja dążeniom do rozwoju zrównoważonego i gospodarki niskowęglowej nie tylko z powodu tego, że rządy mają mniejsze możliwości subsydiowania OZE i wspierania czystych technologii (technologii demonstracyjnych, pilotażowych i przemysłowych). Także sytuacja biznesu jest wtedy niełatwa, gdyż ograniczenie dotacji dla firm inwestujących w OZE, czyste technologie węglowe i efektywność energetyczną oznacza trudniejszy dostęp do kredytu bankowego na inwestycje.

\section{Zakończenie}

W świetle rosnącej presji produkcji i konsumpcji w ostatnim ćwierćwieczu widać, że istnieje wyraźny rozziew między teorią a praktyką rozwoju zrównoważonego. Promocja rozwoju zrównoważonego na szczeblu globalnym idzie $z$ dużymi oporami. Zakres wdrożenia Agendy 21 - niebieskiej księgi rozwoju zrównoważonego na XXI wiek - wspartej przez deklarację z Rio de Janeiro, a zawierającą 27 zasad wdrażania rozwoju zrównoważonego oraz później ukierunkowaną przez konwencję klimatyczną i konwencję o bioróżnorodności nie napawa optymizmem. Wiele ośrodków naukowych, organizacji ekologicznych i organizacji non-profit ocenia, że wdrażanie konwencji, traktatów i deklaracji wynegocjowanych przez rządy w Sztokholmie (1972), Rio de Janeiro (1992), Kioto (1997) i Johanesburgu (2002) pozostawia wiele do życzenia. Tym bardziej że kolejne ostatnie szczyty ziemi (Kopenhaga, Poznań, Cancun) niewiele wniosły nowego, a szczyt w Durbanie w 2011 roku nie dał konkretnych impulsów do ustanowienia nowego ładu klimatycznego. Być może nastąpi to dopiero na szczycie Rio+20 w 2012 roku w Brazylii.

Mimo obserwowanego postępu globalny kapitał naturalny jest w dalszym ciągu nadmiernie zużywany, a obecny styl życia całej społeczności globalnej nie zapewnia pomyślności przyszłym pokoleniom. Zgodzić się trzeba z F. Doddem, który

51 Klimat ważniejszy od demokracji i praw człowieka, wywiad P. Gillerta z Minxin Pei, „Rzeczpospolita” 22.02.2009. 
stwierdza, iż wiele obietnic nie zostało dotrzymanych i dziś kluczowymi wyzwaniami dla rozwoju zrównoważonego pozostaje to, że:

- społeczeństwa żyją ponad wydolność ekologiczną Ziemi,

- obecny model konsumpcji zapewnia możliwości i pomyślność tylko bardziej rozwiniętym państwom, przy znacznym dysparytecie dla większości krajów rozwijających się,

- zmiany klimatyczne pozostają poza kontrolą,

- nie ma dostatecznych związków między środowiskiem a bezpieczeństwem w szerokim tego słowa znaczeniu (energia, woda, żywność, zdrowie, edukacja),

- nie istnieją wystarczające ramy instytucjonalne na poziomie światowym do monitorowania środowiska i doprowadzenia do uzgodnień międzynarodowych przez poszczególne rządy. ${ }^{52}$

W prawie dwadzieścia lat po Rio konieczne jest więc postawienie nowych celów rozwoju zrównoważonego w kierunku zielonej gospodarki, zrównoważonego stylu życia oraz społecznego i dobrowolnego zaangażowania w promocję rozwoju zrównoważonego. W szczególności muszą to być cele związane z energią (clean energy), ochroną klimatu zapewniającą jego trwałość, trwałą konsumpcją i produkcją, bezpieczeństwem żywnościowym i trwałym rolnictwem, dostępem do wody, urbanizacją (clean cities), leśnictwem (healthy forests) i ochroną zasobów morskich (blue economy). Poza tym w celach rozwoju zrównoważonego w dalszym ciągu trzeba uwzględnić problemy bioróżnorodności, egzystencji (walka z ubóstwem), sprawiedliwego dostępu do zasobów środowiska, dostępu do informacji, partycypacji społecznej oraz dążenia do wypracowania nowych wskaźników postępu mierzących rozwój zrównoważony. ${ }^{53} \mathrm{~W}$ dalszym ciągu pozostaje także kwestia wzmocnienia instytucjonalnego rozwoju zrównoważonego na szczeblu globalnym w duchu good governance. Chodzi tu m.in. o powołanie w ramach ONZ Rady Rozwoju Zrównoważonego oraz Światowej Organizacji Środowiska, których zadaniem byłaby skuteczna koordynacja międzynarodowych wysiłków w kierunku osiągnięcia zakładanych obecnie nowych celów rozwoju zrównoważonego.

\section{The new challenges of sustained development}

Diverse perception of natural capital and sustainability in opposite approaches of environmental economics and ecological economics has impact on understanding and defining of sustainable development. Ecological economics approach based on

52 F. Dodd, Only one Earth, World Challenge 2011 - Down to Business - Blog - Only One Earth.mht, 02.09.2011.

53 Draft Declaration of the $64^{\text {th }}$ Annual UN DPI/NGO Conference ,Sustainable Societies: Responsive Citizens", Bonn, Germany, 3-5 September 2011, s. 4 i 10-11. 
strong and very strong sustainability is too ambitious for contemporary generation, although environmental economics approach based on weak sustainability is more realistic, but insufficient. Weaknesses of mainstream economics gave heterodoxy broad field for redefinition of sustainable development and for new synthesis for this socio-economic category. Demographic changes, duplication of Western consumption patterns in emerging economies and intensive pressure of global production and consumption on environment are the reasons why new agreements at international level on climate, energy, food security, access to clean water and protection other natural resources are needed. Effective coordination of actions and application of good governance standards taking into account such matters as human existential problems and needs, equity, access to information, social participation as well as indicators for sustainable development and green economy are also necessary.

\section{Les nouveaux défis du développement durable}

Des différences significatives dans la perception du capital naturel et de la durabilité dans les approches extrêmes de l'économie de l'environnement et de l'économie écologique ont un impact sur la compréhension et la définition de la catégorie du développement durable. L’approche de léconomie écologique basée sur la durabilité forte ou très forte est trop ambitieuse pour la génération contemporaine. Lapproche de léconomie de l'environnement basée sur la durabilité faible est bien plus réaliste, mais elle est insuffisante. Les faiblesses de l'économie dominante sont une opportunité pour une redéfinition et une nouvelle synthèse du développement durable par d'autres courants hétérodoxes. Les changements démographiques, la duplication des modes de consommation occidentaux dans les économies émergentes et la pression intensive de la production et la consommation mondiales sur l'environnement sont les raisons pour lesquelles de nouveaux accords au niveau international sur le climat, lénergie, la sécurité alimentaire, l'accès à l'eau potable et la protection des autres ressources naturelles sont nécessaires. Une coordination efficace de l'application des règles de bonne gouvernance, qui tient compte des questions telles que - les problèmes existentiels de l'homme et ses besoins, la justice, l'accès à l'information, la participation sociale, les indicateurs de développement durable et déconomie verte, est également indispensable. 